\section{JURNAL ABDIMAS

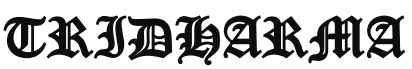

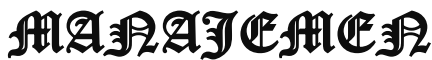

P-ISSN 2715-7105, E-ISSN 2716-070X

Jurnal ABDIMAS Vol. 1,No.2, Mei 2020, Hal (91-98)

@ Prodi Manajemen Fakultas Ekonomi Universitas Pamulang

Email: abdimasjurnal.unpam@gmail.com Telp: (021) 741-2566

\title{
MAHIR MENGGUNAKAN APLIKASI TEMATIS AL-QUR'AN BERBASIS WEB UNTUK PONDOK PESANTREN YAYASAN CINTA RUMAH YATIM JL. RAYA RAWA BUNTU TANGERANG SELATAN
}

\author{
Windy Gustia Wardani*, Akhmar Barsah, Irvan Fauzi, Sinta Sulistiani \\ Dosen Ekonomi Fakultas Ekonomi Universitas Pamulang \\ Email*: dosen01579@unpam.ac.id, dosen01578@unpam.ac.id, \\ dosen01073@unpam.ac.id, dosen01876@unpam.ac.id
}

\begin{abstract}
ABSTRAK
Penelitian ini berjudul Mahir Menggunakan Aplikasi Tematis Al-Qur'an Berbasis Web Untuk Pondok Pesantren Yayasan Cinta Rumah Yatim Jl, Raya Rawa Buntu Tangerang Selatan.

Tujuan pengabdian ini adalah untuk memberikan pemahaman kepada seluruh santri Pondok Pesantren Yayasan Cinta Rumah Yatim, bahwa pentingnya mengetahui Aplikasi Tematis Al-Qur'an Berbasis Web Kepada Seluruh santri pengaruh gadget terhadap prestasi siswa dan memberikan pengetahuan kepada seluruh Pondok Pesantren Yayasan Cinta Rumah Yatim tentang Aplikasi Berbasis Web. Metode pelaksanaan pengabdian ini dilakukan dalam beberapa kegiatan yaitu tahap survei dan sosialisasi mengenai berbagai hal yang akan disampaikan pada saat kegiatan pengabdian. Kegiatan yang akan dilakukan meliputi: penyusunan materi yang akan diberikan, penyusunan jadwal pemberian materi, pembagian tugas tim pengabdi dan survei ke lokasi pengabdian. Tim pelaksanan kegiatan pengabdian pada masyarakat adalah dosen Fakultas Ekonomi jurusan sebanyak 4 orang. Tim pengabdian memerikan materi mengenai Mahir Menggunakan Aplikasi Tematis Al-Qur'an Berbasis Web Untuk Pondok Pesantren Yayasan Cinta Rumah Yatim Jl, Raya Rawa Buntu Tangerang Selatan.

Kesimpulan dari pengabdian ini adalah masih banyak peserta yang kurang memahami mengenai Aplikasi AL-Qur'an Berbasis Web. Harapan kami dengan pengabdian ini dapat membuka wawasan para peserta khususnya dan masyarakat pada umumnya mengenai mahir dalam menggunakan aplikasi tematis Al-Qur'an berbasis Web di zaman sekarang ini serta ilmu yang diperoleh pada Pengabdian Masyarakat ini diharapkan dapat memberikan sengangat baru bagi kita dalam menyampaikan materi dan motivasi serta berkontribusi bagi generasi muda baik di lingkungan sekolan maupun kampus dan keluarga.
\end{abstract}

\section{Kata Kunci : Aplikasi Web, Al-Qur’an, Santri}

\begin{abstract}
This research is titled Advanced Using Web-Based Thematic Al-Qur'an Application for Yayasan Cinta Rumah Yatim Jl, Raya Rawa Buntu, South Tangerang.

The purpose of this service is to provide understanding to all Islamic Boarding School students of the Rumah Cinta Orphan Foundation, that the importance of knowing the Web-based Thematic Application of Al-Qur'an To All students of the influence of gadgets on student achievement and provide knowledge to all Islamic Boarding School
\end{abstract}




\section{JURNAL ABDIMAS

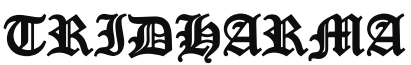

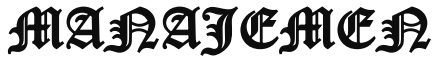

P-ISSN 2715-7105, E-ISSN 2716-070X

Jurnal ABDIMAS Vol. 1,No.2, Mei 2020, Hal (91-98)

@Prodi Manajemen Fakultas Ekonomi Universitas Pamulang

Email: abdimasjurnal.unpam@ gmail.com Telp: (021) 741-2566

Foundation of Rumah Rumah Yatim about Applications Web-based. The method of carrying out this service is carried out in a number of activities, which are the survey and outreach stages of various things that will be delivered at the time of service activities. The activities that will be carried out include: the preparation of material to be given, the preparation of material delivery schedules, the division of tasks of the service team and surveys to the service locations. The community service implementation team consists of 4 lecturers at the Faculty of Economics majoring. The devotion team provided material on Advanced Using the Web-Based Thematic Al-Qur'an Application for Yayasan Cinta Rumah Yatim Jl, Raya Rawa Buntu, South Tangerang.

The conclusion of this dedication is that there are still many participants who lack understanding about Web-based AL-Qur'an Application. Our hope with this dedication can open insight into the participants in particular and the community in general about proficient in using thematic applications of the Web-based Al-Qur'an in today's era and the knowledge gained in Community Service is expected to provide new enthusiasm for us in delivering material and motivation and contribute to the younger generation both in the neighborhood and campus and family.

\section{Keywords: Web Application, Al-Qur'an, Santri}

\section{PENDAHULUAN}

Pembelajaran terhadap aplikasi berbasis web pada para santri pondok pesantren merupakan sarana untuk membekali peserta didik dengan pengetahuan, keterampilan, dan sikap yang diperlukan serta dilakukan untuk melanjutkan pendidikan dan untuk menyesuaikan diri kepada siswa-siswa pondok pesantren dengan perubahanperubahan di sekelilingnya atau di sekitarnya. Pembelajaran para para santri pondok pesantren sejak dini akan menghasilkan generasi dewasa yang melek akan sains dan mampu menghadapi tantangan hidup dalam dunia yang semakin kompetitif dalam kemajuan ilmu komunikasi dan teknologi.

Depdiknas menuturkan bahwa fungsi dan tujuan para santri di pondok pesantren adalah untuk: Mengembangkan keterampilan, sikap, dan nilai tambah bagi para santri pondok pesantren, Mempersiapkan peserta didik pondok pesantren menjadi warga negara atau anak bangsa Indonesia yang melek akan sains dan teknologi informasi dan komunikasi, Menguasai konsep sains untuk bekal hidup di masyarakat dan melanjutkan ke jenjang pendidikan yang lebih tinggi, Tidak semua materi pembelajaran para santri pondok pesantren untuk diamati secara langsung.
Selain itu tidak mungkin menghadirkan objek nyata dalam setiap pembelajaran dan melakukan penelitian ilmiah terhadap semua objek materi para santri pondok pesantren, Penggunaan media juga dapat menambah motivasi belajar para santri pondok pesantren sehingga perhatian terhadap materi pembelajaran yang dapat lebih meningkatkan, Melalui rencana strategis (Renstra) kemendiknas tahun 2010-2014, pemerintah mengharapkan adanya penggunaan teknologi, informasi, dan komunikasi (TIK) dalam kegiatan pembelajaran. Hal ini ditunjukan untuk penguatan dan perluasan e-pembelajaran pada semua jenjang pendidikan.

Berdasarkan fungsi dan tujuan para santri di pondok pesantren menurut Depdiknas tersebut di atas maka prioritas pengabdian kepada masyarakat pada hal permasalahan-permasahan yang ada di pondok pesantren untuk dilakukan perbaikan-perbaikan yang terfokus pada hal berikut: Penerapan pada teknologi dalam pendidikan formal maupun non formal memang mempunyai masalah tersendiri terutama pada sumber daya manusia dalam mengaplikasikan teknologi untuk mendukung aktifitas belajar. Untuk menindaklanjuti transformasi maka butuh waktu dalam memproses transformasi dari suatu sistem yang dulunya sangat sedikit 


\section{JURNAL ABDIMAS

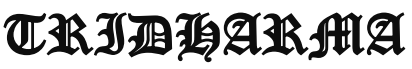

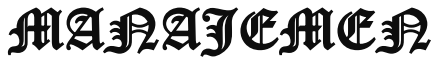

P-ISSN 2715-7105, E-ISSN 2716-070X

Jurnal ABDIMAS Vol. 1,No.2, Mei 2020, Hal (91-98)

@ Prodi Manajemen Fakultas Ekonomi Universitas Pamulang

Email: abdimasjurnal.unpam@ gmail.com Telp: (021) 741-2566 pengetahuannya untuk merubah kedalam aplikasi teknologi ke sistem yang lebih dominan terhadap aplikasi teknologinya karena untuk mendukung aktifitas pembelajaran. Pada masalah masalahmasalah tersebut dapat di uraikan sebagai berikut di bawah ini: (1) Sumber Daya Manusia (SDM), Sumber daya manusia dapat mengembangkan keahlian staf pengajar di dalam kelas agar memilliki kompetensi profesional di bidang Information and Communication Technologies (ICT) adalah payung besar terminologi yang mencakup seluruh peralatan teknis untuk memproses dan menyampaikan informasi. Information and Communication Technologies (ICT) mencakup dua aspek yaitu teknologi informasi dan teknologi komunikasi. Teknologi informasi meliputi segala hal yang berkaitan dengan proses, penggunaan sebagai alat bantu, manipulasi, dan pengelolaan informasi. Sedangkan teknologi komunikasi adalah segala sesuatu yang berkaitan dengan penggunaan alat bantu untuk memproses dan mentransfer data dari perangkat yang satu ke lainnya. Oleh karena itu, teknologi informasi dan teknologi komunikasi adalah dua buah konsep yang tidak terpisahkan. Jadi Teknologi Informasi dan Komunikasi mengandung pengertian luas yaitu segala kegiatan yang terkait dengan pemrosesan, manipulasi, pengelolaan, pemindahan informasi antar media. Istilah Information and Communication Technologies (ICT) muncul setelah adanya perpaduan antara teknologi komputer (baik perangkat keras maupun perangkat lunak) dengan teknologi komunikasi pada pertengahan abad ke-20. Ditambah lagi sikap para pendidik yang enggan untuk mengikuti suatu perubahan dan adanya rasa takut terhadap teknologi informasi baru di sekitar atau di sekelilingnya. Jumlah para peserta pendidik yang mampu untuk mengaplikasian suatu teknologi baru sedikit yang mampu memahaminya. (2) Kurikulum, belum adanya standarisasi dan tanggung jawab pada penerapan teknologi dalam pembelajaran teknologi komputer pada perangkat lunak maupun perangkat keras. Pelaksanaan kurikulum dan pembelajaran belum sepenuhnya memanfaatkan sistem Information and Communication Technologies (ICT). Evaluasi terhadap proses belajar siswa belum mengacu pada penerapan Information and Communication Technologies (ICT). Salah satu solusinya adalah siswa harus bisa melihat hasil ujiannya di situs web sekolahnya seperti yang saat ini banyak diterapkan di perguruan tinggi. (3) Hardware, Sangat banyak masalah yang ditemukan disini. Mulai dari susahnya menyediakan perangkat Information and Communication Technologies (ICT), kurangnya tenaga ahli yang dapat mengoperasikan perangkat, susahnya mengikuti perkembangan Information and Communication Technologies (ICT) yang begitu cepat, sampai terbatasnya dana untuk pemeliharaan serta perbaikan jika terjadi kerusakan. (4) Software, Kurangnya atau sedikit sekali fasilitas pada perangkat lunak yang menyediakan semua materi pelajaran. Terbatasya inovasi dalam pengembangan perangkat lunak untuk mengatasi masalahmasalah dengan penggunaan sistem Information and Communication Technologies (ICT). Dan sangat banyak software yang biasanya mengunakan bahasa asing seperti bahasa inggris. Tentu saja hal itu akan semakin mempersulit dalam penggunaan sitem Information and Communication Technologies (ICT) tersebut, karena harus memahami terlebih duhulu bahasanya dengan menterjemahkannya ke dalam bahasa indonesia. (5) Dana, Pada dana yang di dapat hanya Sedikit yang disediakan untuk memenuhi penerapan sistem Information and Communication Technologies (ICT) ini. Dana tersebut juga harus dibagi untuk semua pemeliharaan pada fasilitas- fasilitas dan perbaikan yang ada di lingkungan pondok pesantren. (6)Terbatasnya dalam fasilitas belajar, contonya seperti: komputer yang terbatas dan bahkan tidak ada, gedung atau kelas yang sempit sehingga tidak ada 


\section{JURNAL ABDIMAS

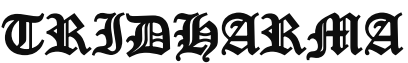

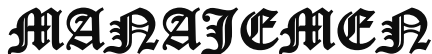

P-ISSN 2715-7105, E-ISSN 2716-070X

Jurnal ABDIMAS Vol. 1,No.2, Mei 2020, Hal (91-98)

@ Prodi Manajemen Fakultas Ekonomi Universitas Pamulang

Email: abdimasjurnal.unpam@ gmail.com Telp: (021) 741-2566 ruang yang cukup untuk tempat meletakan komputer, perpustakaan yang kurang memadai serta terbatasnya buku penunjang pembelajaran terutama buku-buku pembelajaran tentang informasi dan komunikasi pada bidang ilmu teknologi informatika. Namun biasanya ada masalahmasalah diatas banyak dialami oleh pondok pesantren yang berada di daerah tersebut. Karena infrastruktur yang kurang dan kemajuan di suatu tempat dengan tempat yang lain sangat berbeda-beda sekali dengan kemajuan ilmu teknologi informasinya maupun kemampuan finansial serta sumber daya manusia yang ada.

\section{RUMUSAN MASALAH}

Berdasarkan pada uraian di atas peneliti dapat menyimpulkan penting kiranya untuk mengembangkan media pembelajaran ilmu teknologi informasi untuk para santri pondok pesantren dengan memanfaatkan perkembangan teknologi informasi dan komunikasi di lingkungan sekitar atau di sekelilingnya. Pengembangan tersebut berupa pengembangan media pembelajaran para santri berbasis website. Pada latar belakang tersebut, kami dari Tim Program studi manajemen dalam Pengabdian kepada Masyarakat (PKM) Universitas Pamulang yang berjumlah 4 dosen dan dalam hal ini kami akan melaksanakan pengabdian kepada masyarakat dengan tema "MAHIR MENGGUNAKAN APLIKASI TEMATIS ALQURAN BERBASIS WEB UNTUK SISWA PONDOK PESANTREN"

\section{TUJUAN PELAKSANAAN}

Tujuan umum dari kegiatan pengabdian kepada masyarakat ini adalah membantu siswa Pondok Pesantren Yayasan Cinta Rumah Yatim Jl. Raya Rawa Buntu Tangerang Selatan. Mempersiapkan diri untuk Mahir menggunakan aplikasi tematis Al- Qur'an berbasis web. Secara Khusus tujuan pengabdian kepada masyarakat ini adalah:
1. Memberikan pengetahuan tentang aplikasi berbasis web

2. Melaksanakan rencana pelatihan untuk aplikasi tematis Al Quran berbasis web.

3. Memberikan pendampingan serta bimbingan teknis kepada santri tentang aplikasi tematis Al Quran berbasis web

4. Memberikan pengenalan tentang aplikasi tematis Al Quran berbasis web.

\section{TINJAUAN PUSTAKA}

\section{Pengertian Manajemen}

Pengertian manajemen menurut Haimann mengatakan bahwa manajemen adalah fungsi untuk mencapai sesuatu melalui kegiatan orang lain dan mengawasi usaha-usaha individu untuk mencapai sesuatu melalui kegiatan orang lain dan mengawasi usaha-usaha individu untuk mencapai tujuan Bersama.

Secara etimoligi manajemen berasal dari kata to Manage yang artinya mengatur. Bila dilihat dari literatur-literatur yang ada, pengertian manajemen dapat dilihat dari tiga pengertian; manajemen sebagai suatu proses, manajemen sebagai suatu kolektivitas manusia, manajemen sebagai ilmu (science) dan sebagai seni (art).Secara umum, pengertian manajemen merupakan suatu seni dalam ilmu dan pengorganisasian seperti menyusun perencanaan, membangun organisai dan pengorganisasiannya, pergerakan serta pengendalian atau pengawasan. Bisa juga diartikan bahwa manajemen merupakan suatu ilmu pengetahuan yang sistematis agar dapat memahami mengapa dan bagaimana manusia saling bekerja sama agar dapat menghasilkan sesuatu yag bermanfaat bagi orang lain maupun golongan tertentu dn masyarakat luas.

Secara etimologis, pengertian manajemen merupakan seni untuk melaksanakan dan mengatur. Manajemen juga dapat dilihat sebagai ilmu yang mengajarkan proses mendapatkan tujuan 


\section{JURNAL ABDIMAS

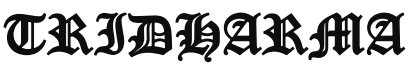

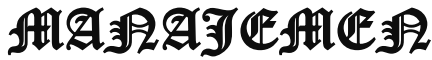

P-ISSN 2715-7105, E-ISSN 2716-070X

Jurnal ABDIMAS Vol. 1,No.2, Mei 2020, Hal (91-98)

@ Prodi Manajemen Fakultas Ekonomi Universitas Pamulang

Email: abdimasjurnal.unpam@ gmail.com Telp: (021) 741-2566 dalam organisai, sebagai usaha bersama dengan beberapa orang dalam organisasi tersebut. Sehingga, ada orang yang merumuskan dan melaksanakan tindakan manajemen yang disebut dengan manajer.

\section{Fungsi Manajemen}

Pada dasarnya, fungsi manajemen dibagi menjai tiga, yaitu :

a. Perencanaan (planning)

Perecanaan adalah memikirkan apa yang akan dikerjakan dengan sumber yang dimiliki. Perencanaan dilakukan untuk menentukan tujuan perusahaan secara keseluruhan dan cara terbaik untuk memenuhi tujuan itu. Manajer mengevaluasi berbagai rencana alternative sebelum mengambil tindakan dan kemudian melihat apakah rencana yang dipilih cocok dan dapat digunakan umtuk memenuhi tujuan perusahaan. Perencanaan merupakan proses terpenting dari semua fungsi manajemen karena tanpa perencanaan, fungsi-fungsi lainnya tak dapat berjalan.

b. Pengorganisasian (organizing)

Pengorganisasian dilakukan dengan tujuan membagi suatu kegiatan besar menjadi kegiatan-kegiatan yang lebih kecil. Pengorganisasian mempermudah manajer dalam melakukan pengawasan dan menentukan orang yang dibutuhkan untuk melaksanakan tugas-tugas yang telah dibagi-bagi tersebut. Pengorganisasian dapat dilakukan dengan cara menentukan tugas apa yag harus dikerjakan, siapa yang harus mengerjakan, bagaimana tugas-tugas tersebut dikelompokkan, siapa yang bertanggungjawab atas tugas tersebut, dan pada tingkatan mana keputusan harus diambil.

c. Pengarahan (directing)

Pengarahan adalah suatu tingakan untuk mengusahakan agar semua anggota kelompok berusaha agar dapat mencapai sasaran sesuai dengan perencanaan manajerial dan usaha.

Setiap perusahaan memiliki unsur-unsur untuk membentuk system manajerial yang baik. Unsur-unsur inilah yang disebut unsur manajemen. Jika salah satu diantaranya tidak sempurna atau tidak ada maka akan berimbas dengan berkurangnya upaya untuk mencapai tujuan.

\section{Pengertian Aplikasi}

Istilah aplikasi berasal dari bahasa inggris "application" yang berarti penerapan, lamaran atau penggunaan. Sedangkan secara istilah, pengertian aplikasi adalah suatu program yang siap untuk digunakan yang dibuat untuk melaksanakan suatu fungsi bagi pengguna jasa aplikasi serta penggunaan aplikasi lain yang dapat digunakan oleh suatu sasaran yang akan dituju.

Menurut Jack Febrian (2005: 35), "Aplikasi merupakan program siap pakai yang digunakan manusia dalam melakukan pekerjaan menggunakan komputer". Menurut kamus komputer eksekutif, aplikasi mempunyai arti yaitu pemecahan masalah yang menggunakan salah satu teknik pemrosesan data aplikasi yang biasanya berpacu pada sebuah komputasi yang diinginkan atau 3 diharapkan maupun pemrosesan data yang diharapkan. Sedangkan pengertian menurut Jogiyanto Hartono (2004: 8), "Aplikasi merupakan sistem yang dirancang dan disusun sedemikian rupa untuk menghasilkan informasi yang terpadu dengan menggunakan sarana komputer sebagai sarana penunjangnya".

Dari definisi mengenai aplikasi diatas dapat disimpulkan bahwa aplikasi adalah suatu sub kelas perangkat lunak komputer yang memanfaatkan kemampuan komputer langsung untuk melakukan suatu tugas tertentu yang dapat menghasilkan informasi dengan menggunakan aturan atau ketentuan bahasa pemrograman yang dikehendaki terhadap penggunanya.

\section{Al-Qur'an}

Pengertian al-Qur'an secara bahasa telah dikemukakan oleh para ahli dalam sejumlah pendapat yang berangkat dari cara penulisan serta pengakaran kata yang berbeda. Subhi al-Salih sebagaimana 


\section{JURNAL ABDIMAS

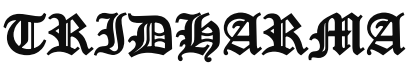

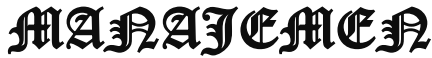

P-ISSN 2715-7105, E-ISSN 2716-070X

Jurnal ABDIMAS Vol. 1,No.2, Mei 2020, Hal (91-98)

@ Prodi Manajemen Fakultas Ekonomi Universitas Pamulang

Email: abdimasjurnal.unpam@ gmail.com Telp: (021) 741-2566 dikutip oleh Suf Kasman mengkategorisasikannya dalam dua kelompok; mereka yang menuliskan kata Al-Qur'an dengan imbuhan huruf hamzah dan mereka yang tidak membubuhinya. Termasuk kelompok pertama adalah alSyafi'i, al- Farra', dan al-Asy'ari. Sedangkan yang termasuk kelompok kedua adalah al-Zajjaj, al-Lihyani serta jamaah lainnya.

Menurut Subhi al-Salih, Manna ${ }^{\text {ee }}$ alQattan, Muhammad Salim Muhsin dan Muhammad Bakr Ismail sebagaimana yang dikutip Suf Kasman bahwa pendapat yang terakhir ini lebih kuat dan lebih tepat, sebab kata Al-Qu'an dalam bahasa Arab merupakan masdar yang paralel dengan kata qira'ah, yaitu bacaan (Suf Kasman, 2004; 120-121).

Menurut al-Lihyani, kata Al-Qur'an berasal dari kata qara'ayaqra'u qira'atan yang berarti membaca dan mengikuti pola kata al-rujhan dan al-gufran.

Definisi Al-Qur'an menurut Ali ashShabuni seperti yang dikutip oleh Mashuri Sirojuddin Iqbal dan Ahmad Fudloli dalam buku Pengantar Ilmu Tafsir adalah kalamullah (firman Allah) yang mengandung mukjizat yang diturunkan kepada penutup para nabi dan rasul, dengan perantaraan yang dapat dipercaya yaitu malaikat Jibril, yang ditulis dalam mushaf dan diriwayatkan kepada kita secara mutawwatir, serta diperintahkan membacanya, diawali dengan surat alFatihah dan diakhiri dengan surat an- Nas (Mashuri Sirojuddin Iqbal dan Ahmad Fudlali, 1989; 3 \& 17).

Menyimpulkan bahwa definisi diatas mengenai Al Qur'an adalah kalam Allah yang disampaikan kepada Nabi Muhammad Saw melalui Malaikat Jibril yang merupakan mukjizat, membaca dan mempelajarinya adalah bernilai ibadah.

\section{Web}

Web adalah fasilitasyang paling sering digunakan dan diakses setiap orang di internet. Web sudah berkembang sedemikian pesat dewasa ini. Banyak sekali web baru bermunculan di internat. Perkembangan web tersebut menarik minat setiap orang untuk mempelajari bagaimana membuatnya. Membuat web tidaklah susah. Sebuah web sederhana dan informatif dapat dibuat dengan cepat menggunakan HTML, CSS, dan JavaScript.

Definisi atau pengertian aplikasi berbasis web adalah sebuah aplikasi yang dapat diakses menggunakan web browser atau penjelajah web melalui jaringan internet atau intranet.

Meskipun hingga saat ini ternyata lebih banyak, lebih luas, dan lebih komersil dalam pemakaiannya. Banyak dari perusahaan-perusahaan berkembang yang menggunakan aplikasi berbasis web dalam merencanakan sumber daya mereka dan untuk mengelola perusahaan mereka. Beberapa yang lain mendefinisikan bahwa pengertian aplikasi web adalah program yang tersimpan pada server kemudian dikirim melalui internet dan diakses melalui antar muka atau interface berupa web browser.

\section{METODE PELAKSANAAN}

Metode pelaksanaan pengabdian ini dilakukan dalam beberapa kegiatan yaitu dengan survei kemudian menyusun berbagai hal yang akan disampaikan pada saat kegiatan pengabdian yang akan dilakukan. Kemudian tahap sosialisasi sebelum kegiatan pengabdian dilaksanakan dengan melakukan silaturahmi dengan ketua yayasan serta menyampaikan maksud dan tujuan dari pengabdian ini. Tim pelaksana kegiatan pengabdian pada masyarakat adalah dosen Fakultas Ekonomi jurusan Manajemen sebanyak 4 orang. Tim pengabdian memberikan pelatihan mengenai Mahir Menggunakan Aplikasi Tematis Al-Qur'an Berbasis Web Untuk Pondok Pesantren Yayasan Cinta Rumah Yatim Jl. Raya Rawa Buntu Tangerang Selatan. Pelatihan ini dilaksanakan pada tanggal 03, 04, 05 Januari 2020. Pelatihan ini bertujuan untuk mengetahui betapa pentingnya Aplikasi Tematis Al-Qur'an Berbasis Web terhadap prestasi santri. 


\section{JURNAL ABDIMAS

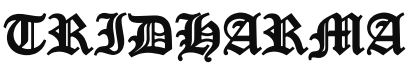

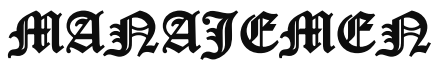

P-ISSN 2715-7105, E-ISSN 2716-070X

Jurnal ABDIMAS Vol. 1,No.2, Mei 2020, Hal (91-98)

@ Prodi Manajemen Fakultas Ekonomi Universitas Pamulang

Email: abdimasjurnal.unpam@ gmail.com Telp: (021) 741-2566

\section{HASIL DAN PEMBAHASAN}

Pengabdian Kepada Masyarakat (PKM) Universitas Pamulang dilakukan oleh dosen-dosen program studi Manajemen telah berjalan dengan lancar dan mendapat sambutan hangat dari para peserta kegiatan ini yaitu para santri dari Pondok Pesantren Yayasan Cinta Rumah Yatim Jl. Raya Rawa Buntu Tangerang Selatan.

Kegiatan pengabdian kepada masyarakat (PKM) merupakan salah satu bagian dari tri dharma perguruan tinggi yang harus dilaksanakan oleh dosen perguruan tinggi negeri atau swasta. Pengabdian masyarakat oleh dosen merupakan hilirisasi hasil penelitian dosen atau kajian akademis di perguruan tinggi agar dapat dimanfaatkan oleh masyarakat baik berupa ilmu pengetahuan maupun teknologi. Dengan harapan dasarnya adalah dapat merubah kehidupan menjadi lebih baik. Pengabdian kepada masyarakat dapat diberikan kepada kelompok masyarakat yang terdidik maupun yang lain.

PKM yang dilakukan oleh tim pengabdian kepada masyarakat prodi manajemen ini merupakan hilirisasi pengetahuan, pengkajian akademis di perguruan tinggi selanjutnya untuk dimanfaatkan oleh kelompok terdidik yakni santri Panti Asuhan Al-Ikhwaniyah Cinta Yatim \& Dhuafa Cabang Serpong dan Tangerang Selatan. Pelatihan disusun secara sistematis dan disampaikan dengan menggunakan metode yang tepat, dengan harapan diperoleh hasil yang sesuai dengan apa yang diharapkan.

Berdasarkan data ketercapaian target di atas, dapat diketahui bahwa terdapat empat tahapan dalam merealisasikn dan memaksimalkan kegiatan PKM ini. Tahapan pertama, memberikan pengetahuan tentang aplikasi berbasis web. Pada tahapan ini santri diberi pengetahuan sebagai wawasan awal bagi mereka dalam memahami apa itu aplikasi dan web. Setelah memahami makna dan manfaat dari plikasi dan web, selanjutnya santri diajak untuk mempelajari aplikasi yang berbasis web.

Tahapan kedua dalam kegiatan ini adalah melaksanakan rencana pelatihan untuk aplikasi tematis Al Quran berbasis web. Pada tahap ini santri berlatih secara langsung terkit aplikasi tematis Al Quran berbasis web. Dengan terjun secara langsung, santri dapat merasakan dan tau seperti apa bentuk dan jenis aplikasi yang berbasis web. Selanjutnya, diharapkan santri mampu mengetahui manfaat dan mengoperasikannya dengan baik dan benar. Adapun tahapan yang ketiga kegiatan ini adalah memberikan pendampingan serta bimbingan teknis kepada santri tentang aplikasi tematis $\mathrm{Al}$ Quran berbasis web. Setelah santri mengetahui bentuk, jenis dan manfaat dari aplikasi berbasis web, santri diharapkan dapat mengoperasikan aplikasi tersebut dengan baik dan benar. Dengan demikian, alhasil para santri kelak dapat memnfaatkannya dengan maksimal demi tercapainya cita-cita mereka yang diantaranya adalah memahami ilmu-ilmu agama dengan baik dan menjadi seorang pendakwah.

Tahapan terakhir dalam kegiatan ini adalah memberikan pengenalan tentang aplikasi tematis Al Quran berbasis web. Setelah

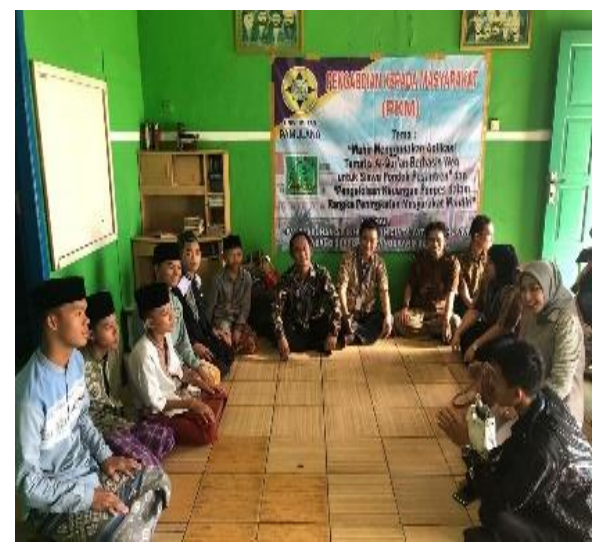




\section{JURNAL ABDIMAS

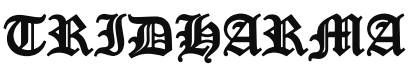

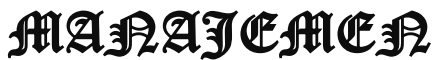

P-ISSN 2715-7105, E-ISSN 2716-070X

Jurnal ABDIMAS Vol. 1,No.2, Mei 2020, Hal (91-98)

@ Prodi Manajemen Fakultas Ekonomi Universitas Pamulang

Email: abdimasjurnal.unpam@ gmail.com Telp: (021) 741-2566 mencoba aplikasi berbasis web, santri diajak untuk mengetahui macam-macam aplikasi berbasis web

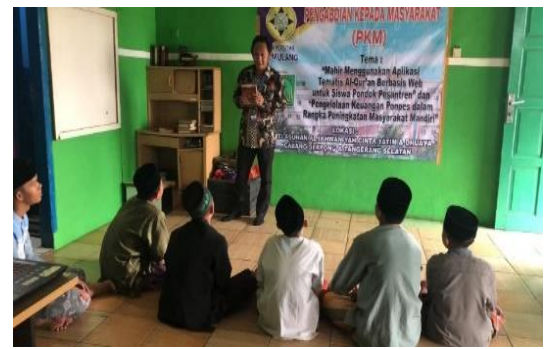

khususnya aplikasi tematis al Qur'an. Dengan mengetahui macam-macam aplikasi tersebut, diharapkan santri dapat mengembangkan kemampuannya dalam mengembangkan pemahamannya dalam hal mengoperasikan aplikasi berbasis web. Disamping itu, hal; tersebut dapat membantu mereka dalam mencapai citacita luhur mereka melalui ilmu pengetahuan berbasis teknologi.

\section{KESIMPULAN DAN SARAN \\ Kesimpulan}

Berdasarkan hasil kegiatan PKM yang kami laksanakan, dapat disimpulkan bahwa kegiatan PKM ini Alhamdulillah berjalan lancar tanpa ada kendala yang berarti. Semua materi yang dipersiapkan dapat tersampaikan dengan baik dan maksimal. Berdasarkan tahapan-tahapan kegiatan yang telah dilakukan dalam kegiatan ini menunjukkan adanya peningkatan pemahaman santri dalam hal aplikasi berbasis web khususnya aplikasi tematis al Qur'an berbasis web. Disamping itu, santri juga menunjukkan reaksi yang positif dalam mengikuti kegiatan serta pemahaman peserta pelatihan terhadap daya serap materi yang disajikan juga cukup baik. Daya serap cukup baik ini dapat dilihat dari kognisi/pengetahuan yang dimiliki peserta pelatihan perihal subyek materi yang disampaikan. Selain itu, pada level psikomotorik atau ketrampilan menunjukkan hasil yang baik yakni mampu melakukan kegiatan praktik yang diberikan oleh Tim PKM dengan baik.

Saran

Setelah pengabdian ini diharapkan para peserta dapat lebih mengerti dan memahami mengenai MAhir menggunakan Aplikasi Tematis Al-Qur'an berbasis Web untuk santri. Panti Asuhan Al-Ikhwaniyah Cinta Yatim \& Dhuafa Cabang Serpong dan Tangerang Selatan secara terintegrasi perlu diperkuat lagi, sebab pendidikan berbasis teknologi menjadikan santri yang melek teknologi di era modern seperti saat ini.

\section{DAFTAR PUSTAKA}

As-Syilasyabi, Abu Yahya. 2007. Cara Mudah Membaca Al-Qur'an Sesuai Kaidah Tajwid. Yogyakarta: Daar Ibnu Hamz.

Febrian, Jack. 2007. Kamus Komputer dan Teknologi Informasi. Bandung: Informatika.

Firmansyah, anang dan Budi W Mahardhika. 2018. Pengantar Manajemen. Sleman: CV Budi Utama.

Hasibuan, S.P Malayu. 2002. Organisasi dan Motivasi : Dasar Peningkatan Produktifitas, Jakarta: Bumi Aksara.

Ramadhan, Arief. 2006. Student Guide Series Pemrograman Web. Jakarta: PT Elex Media Komputindo.

Sobri, Muhammad.,dkk. 2017. Pengantar Teknologi Informasi.Yogyakarta: ANDI.

Wijaksono, Arief., Anis Farihah., \& Novia Ariyanti (2018). APLIKASI TEMATIS ALQURAN BERBASIS WEB. Jurnal Aksiologiya, 2(2) 